 \\ International Journal of Social Sciences and Management
}

\section{A Rapid Publishing Journal}

ISSN 2091-2986

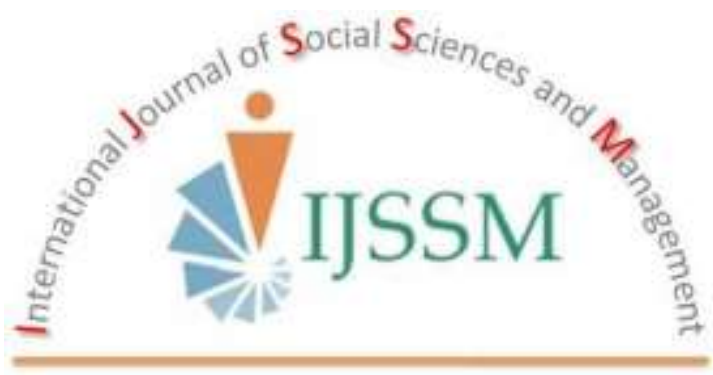

\section{Indexing and Abstracting}

CrossRef, Google Scholar, International Society of Universal Research in Sciences (EyeSource), Journal TOCs, New Jour, Scientific Indexing Services, InfoBase Index, Open Academic Journals Index (OAJI), Scholarsteer, Jour Informatics, Directory of Research Journals Indexing (DRJI), International Society for Research Activity (ISRA): Journal Impact Factor (JIF), Simon Fraser University Library, etc.

Vol- 2(4), October 2015 


\title{
EVOLUTION OF GOVERNMENT ARTS COLLEGE, ANANTHAPURAMU IN TEN DECADES: A STUDY
}

\author{
D. Sahadevudu ${ }^{1 *}$, C. Venkateswarulu ${ }^{2}$, Y. RamachandraReddy ${ }^{3}$ and N. Rangaswamy ${ }^{4}$ \\ ${ }^{1}$ Govt. College (M), Ananthapuramu-515001, Andhrapradesh, India. \\ ${ }^{2}$ M.S.Degree College Gooty-515401, Andhrapradesh, India. \\ ${ }^{3}$ Department of History, S.K. University, Ananthapur-515003, Andhrapradesh, India. \\ ${ }^{4}$ Govt. College (M), Ananthapuramu-515001, Andhrapradesh, India. \\ *Corresponding author's email: sahadevdevangula@gmail.com
}

\begin{abstract}
Ananthapur Arts College is an oasis in the desert of Rayalaseema education. It is the oldest and most prestigious government institution in the Rayalaseema region and people often calls it "The Grand Old Lady of Rayalaseema". This institution can take legitimate pride in recalling some of its alumni and the greatness they have achieved in several fields. Its distinctive history, its gradual growth and development, its adaptability to the ever - changing times and its mission make it unique has compare to the other institutions. This college has a vibrant work culture and holistic approach to education. Many people of this region rose from dust to doyen by this college. This college has completed 99 years of yeoman service to the noble cause of education. On the occasion of going centenary celebrations it behoves on us to look back to its beginning, growth and the rich contribution made by way of its alumni who have become celebrated in different walks of life. The 100 years of its history have to their credit many landmarks which have an abiding relevance when viewed in the context of the responsiveness of the College to the growing demands of the Rayalaseema.On such a happy and jubilant occasion as this, it is but proper to recall the history of the college.
\end{abstract}

Key Words: Evolution; centenary celebration; Alumni; Education; Institution.

\section{Introduction}

Govt. Arts College, Ananthapuramu started as the "Ceded Districts College" in 1916, renamed as "Govt. Arts College" in 1947.It is the oldest and most prestigious government institution in the Rayalaseema region and people often calls it "The Grand Old Lady of Rayalaseema". This college has completed 99 years of yeoman service to the noble cause of education. On the occasion of going centenary celebrations it behoves on us to look back to its beginning, growth and the rich contribution made by way of its alumni who have become celebrated in different walks of life. On such a happy and jubilant occasion as this, it is but proper to recall some of the great deeds of those brave children of the college. The 100 years of its history have to their credit many landmarks which have an abiding relevance when viewed in the context of the responsiveness of the College to the growing demands of the Rayalaseema comprising four districts of Andhrapradesh state.

\section{Methodology}

The present study on "Evolution of Government Arts College, Ananthapuramu in Ten Decades: A study" is based on historical method. This research is based on a good deal of primary and secondary sources that are available. We depend on primary resources like Foundation stones, Gazetteers, College Annual reports, Institution Souvenirs,
NAAC records; Reaccreditation reports and University reports regarding Government Arts College, Ananthapuramu for collecting information. It is not recorded properly so for in any texts, though Anantapur Gazetteers gives some information on this college and diverse collection of secondary sources for the study were also consulted. Now it is the correct time juncture to give proper record in the annals of history on the occasion of centenary celebrations of this Institution.

\section{Origin of Government Arts College}

Ananthapuramu former municipal Chairman Pulimiti Adimurthy Rao's efforts succeeded to set up secondary grade college by Madras government. He initiated to allot municipal high school building to the new college, which makes not to swift this college for Bellary. On the 8th July, 1916 the Ceded District College was started as a Second Grade College, J.H. Stone directorate of Public instructions of Madras, appointed S.E. Ranganathan as first principal and Survepalli Radhakrishnan was one of the first leading Lecturers. This college blessed him to become future President of India. Mark Hunter recommended to Madras government to give two years recognition to this new college (RamachandraRao, 1978). 


\section{Evolution of Government Arts College}

The first decade saw to it the teething troubles were got over smoothly. Based on the report of a University commission which was headed by Prof. Mark Hunter, affiliation to the Madras University was given at the first instance, for two years. There was a secondary training school which remained attached to this college up to 1923 and then it was shifted to Bellary. On 6-6-1918 the college was given first grade status and it had the unique honour of being inaugurated by Lord Pent land (Foundation stone of Ceded District College, 1918). On the occasion of the inauguration many prominent men of the region came forward to institute endowment prizes and scholarships, of which Rao Saheb M Hampaiah was a pioneer. Hostel facilities were also provided to the students by constructing the old block of the hostel in 1917. New wings were constructed with the generous presentation of material made by Sri. K.C. Krishna Reddy, a cricket enthusiast, a bright cricket team came up to add glamour to the different activities in the college. Under the president ship of Diwan Bahadur Kesava Pillai, the first college day celebrated on 23rd October, 1920 (RamachandraRao, 1978).

During the second decade, there was a rapid expansion of buildings and increase in the intake of pupils. The old boys association had its inceptions in this period. In 1926 the college was affiliated to the Andhra University for three years and later it was brought back to the Madras University in 1930. The new block of the hostel was constructed in 1930 (Foundation stone of Ceded District College, 1930).

The Third decade saw C.D.S. Chetty an educationist of long and varied experience, as principal, under his aegis, the college acquired a leading status. It was a period of further expansion in several directions. An ambulance division affiliated to St. John ambulance Brigade of Madras was started in 1940. Tutorial classes, poor boy's fund, photographic club, excursion, exhibition and economic survey were innovative series initiated by this doyen. In tune with political temper prevailing in the Nation when the clamour for Freedom struggle was as its peak, there was tremendous political awakening in the campus. Several budding politicians came into limelight. The college also saw the starting of the University Officers Training Corps in 1944-45 which formed a part of the first Madras battalion U.O.T.C. (Sivasankaranarayana, 1970).

On the completion of nearly three decades of brilliant academic fulfilment, the college proudly celebrated its Silver Jubilee in February, 1946 while P.N.Gowd was the principal. This august function was graced by the presence of Justice P.V. Rajamannar, Sri O. Pullaredy and Kavi Samrat Viswanatha Sathyanarayana. Justice Rajamannar laid the foundation stone for the Silver Jubilee memorial pillar. Many Silver Jubilee endowment prizes and scholarships were instituted on this historic occasion (Sivasankaranarayana, 1970).
The Fourth decade saw the birth of the college advisory council which comprised seven members chosen from among the prominent citizens of the district, with principal as its convener, for advising the principal in matters of the admissions, improvement of buildings, expansion of courses and allied matters. The college was renamed as Government Arts College in1947 (Sivasankaranarayana, 1970). The U.O.T.C. changed its complexion was converted into National Cadet Corps. After the formation of the Andhra state, the college was affiliated to the Andhra University and later to the Sri Venkateswara University after its inception (Sivasankaranarayana, 1970.

In the fifth decade, when N.R. Deendayal was the principal; he had to his credit the opening of the Evening Courses which provided opportunities for the aspiring employees to acquire higher academic qualifications. With the abolition of the college selection committee, the entire responsibility of selecting applicants for the various courses of studies devolved on the shoulders of the principal (RamachandraRao, 1978).

The sixth decade witnessed a steady swelling of the student enrolment, with the addition of B.Com course to the other traditional courses. While Y. Viswanatham was the principal, the college accommodated in its campus the newly started post graduate centre, which continued to stay alongside its sister institution until it has its own building. The college was identified as a "Lead College" with a view to preparing it eventually for academic autonomy (RamachandraRao, 1978). The U.G.C. came forward with generous assistance for the purchase of science equipment, development of play fields and purchase of library books, journals (RamachandraRao, 1978).

Further in the seventh decade witnessed the most significant event of the Golden Jubilee celebration of the college in October 1978, which was inaugurated by the Honourable President Neelam SanjeevaReddy, who was an illustrious alumnus of the college. Neelam SanjeevaReddy laid the foundation stone for the Golden Jubilee memorial pillar. Many Golden Jubilee endowment prizes and scholarships were instituted on this historic occasion (RamachandraRao, 1978).

The eighth decade saw the expansion of library block and construction of water tank for drinking facilities to the students in the campus. In this phase faculty forum was inaugurated by K. Venkatasivaiah, I.A.S. Commissioner of Collegiate Education (Foundation Stone, Renovated Library Block of Govt. College, 1993).

In the ninth decade witnessed the foundation of Regional Co-Ordination Centre of Dr. B.R. Ambedkar Open University by Prof. D. RamaChandram, Vice Chancellor in the college campus. Dr.Y. Thimmappa, Principal of this college with his elaborate efforts along with the staff Govt. Arts College Accredited with 'A' Grade by NAAC on 28th February, 2005 (FoundationStone, Govt. Arts College, 2005). 
In the tenth decade, rapid development of the college occurred in various dimensions. Additional class rooms constructions, Computer Lab inauguration, opening of Conference Hall, construction of New Hostel Block, Excellent Gym and Walking Track in the ground were the major developments occurred in the college campus. In this phase a beautiful entrance gate for the college built by the contribution of Alumnus and donors (Foundation Stone, Govt. Arts College, 2011). Major Dr. B. Muralidhara Rao, Principal of this college with his sustainable efforts along with the staff, Alumnus and students Govt. Arts College ReAccredited with 'A' Grade by NAAC on 15th September, 2011. In this period, Govt. Arts College expanded in academic era with the inception of many Post Graduation Courses as well as in student's strength in UG courses (Reaccreditation Report, Govt. Arts College, 2011).

\section{Alumni of Government Arts College}

This institution can take legitimate pride in recalling some of its alumni and the greatness they have achieved in several fields. The pride of place goes to the statesman who came out of the portals of the college. Foremost of them all is Neelam SanjeevaReddy the former President of India. Damodaranm Sanjeevaiah who rose from a humble passion to the eminent heights of Chief Minister Ship and President Ship of AICC is another illustrious alumnus. Pappur Ramacharyulu a class Politian, combined politics with literary achievements of permanent value. Present polititical leaders Dr. Palle RaghunathReddy, Minister of AP, Kaluva Srinivasulu, Chief Whip,JC Diwakar Reddy, Member of Parliament, V. Prabhakar Chowdary, MLA, JC Prabhakar Reddy, MLA,G.Thippeswamy, MLC, Y.Visweswara Reddy, MLA, Dr. Sake Sailajanath, Ex. Minister,Dr. N.Raghuveera Reddy, Ex. Minister E.Ayyapa Reddy, Ex. Minister,K.M.Saifulla, Ex. MP, Anantha Venkramireddy, Ex. MP,Ramakrishna Ex. MLA, Kothakota Prakash Reddy, Ex MLA, were alumnus of this great Institution (Reaccreditation Report, Govt. Arts College, 2011).

Many products of this college are donning the highest positions in different cadres of All India Services. Dr.Y.Venugopal Reddy, IAS, Chairman, 14th Finance Commission, K. Lakshminarayana, IAS, Raghavendra Rao, IAS,.V.D.Rajagopal, IAS,.L. Premachandra Reddy, IAS, Ramanjaneyulu, IAS Ramasankar Naik, IASR Prabhakar Rao, IPS, Ex DGP of AP State Dr. Aravindarao, IPS, DGP. A.K. Khan IPS, J.V. Ramudu, IPS. Narasimhappa, IRS, Chief IT Commissioner were alumnus of this great Institution (Reaccreditation Report, Govt. Arts College, 2011).

S. Obulareddy retired Chief Justice of AP high court is another distinguished alumnus of this college. Judges Justice K. Jayachandra Reddy, Former Judge of Supreme Court, Justice S. Obulareddy, Former Chief Justice of AP High Court, Justice O. Chinnapareddy, Former Judge of Supreme Court, Justice Mothilal B. Naik, Former Chief
Justice of AP High Court, Justice Challa Kondaih, Former Chief Justice of AP High Court are alumnus of this college. Dr. OR Reddy, VC, BROU, Dr. A. Sankar Reddy, VC, Sikkim University, Dr. O. Pulla Reddy, VC, AP Agriculture University, Dr. K. Hanumanthappa, VC, Bangalore, University, Dr. N. Shanthappa VC, was Vice Chancellors of various Universities are alumnus of this college.

Scientists of repute are products of this pioneer institution. To name a few, Prof. U.R. Rao, Director ISRO is one of the most renowned scientists. D.V. Reddy retired Director, Ministry of Defence, D.S. Rao, Coordinator of industrial and technology problems in ISRO and Dr. B.S.N. Rao chief engineer of T.V and broadcasting in Kuwait, are a few of the college. Dr. M. Santhappa, Director, Central Leather Research Institute Madras is the recipient of the most coveted Bhatnagar award. Dr. V.R. Venugopal, Director, Radio Astronomy Centre, Ooty, Dr. H.R. Ramarao, Principle Scientific Officer in SHAR, Dr. B. Ramarao, Head of the X-ray Department, National Physical Labaratory, Hyderabad, Dr. D. Muralidhar, Advisor to New York Corporation on Hydraulics, Dr. P. Sivareddy, Director of Ophthalmology, Sarojinidevi eye hospital, Dr. U. Brahmaji Rao, Professor and head of the department of cardiology Osmania Medical College, Hyderabad, artists, Sandhaya vandanam Srinivasa Rao, Principal of Music College for teachers, Madras, is a renowned exponent Carnatic Music; Roddam Hanumantha Rao stage actor; Kalluri Venkatanarayana Rao is towering personality in the field of literature, were another distinguished alumnus of this Institution (Reaccreditation Report, Govt. Arts College, 2011).

This college is proud of having sheltered under its wing many scholars of repute. Starting with Dr. Sarvepalli Radhakrishnan, it had the services of stalwarts like Veturi Prabhakara Sasthri, Dr. Puttaparthi Narayanacharyulu, Dr. Chilukuri Narayana Rao, Cherukupalli Jamadagni Sharma, P.B. Patnaik, Prof. S. Ramaswamy, Damerla Venkatarao and Sundara Sasthri were eminent alumnus staff of this college.

\section{Development of Government Arts College}

From the first principal S.E. Ranganathan in 1916 to the present principal Dr. N. Rangaswamy of this institution made a brilliant effort in the development of the college in various dimensions. To start with there were 41 students now it swelled into 7,000 students. The college initially offered 5 courses now it has been offering 39 UG courses and 16 PG courses. At beginning the college hostel accommodated only 22 students, now it accommodating 2,000 students. To start with the college library having only 1,000 volumes now it accumulated 70,000 volumes (The Annual Quality Assurance Report of IQAC Govt. Arts College, 2012-13).

Its distinctive history, its gradual growth and development, its adaptability to the ever - changing times and its mission 
make it unique has compare to the other institutions. The College has many unique features. Besides being the Lead college it has the Jawahar Knowledge Centre, the student managed hostel, two senior NCC units, five NSS units, a very big Central Library a reading room, academic and career guidance room, eco club, student open forum, inspiration point, grievances redress cell, etc.

This college has a vibrant work culture and holistic approach to education. The simultaneous development of intellectual, physical, cultural and emotional faculties of the students is achieved through various academic, co curricular and extracurricular activities. Several inter disciplinary and need-based courses offered by the college to help the students develop their potential for the competitive employment market.

Ananthapuramu Arts College is an oasis in the desert of Rayalaseema education. This college created number of Teachers, Lecturers, Scholars, Civil Servants, Scientists, Philosophers, Judges, Lawyers, Soldiers, Police, Artists, Economists, Journalists, Managers, Social Activists and good Leaders to the society. This college provided good number of efficient Employees for public and private sectors. Arts College shaped the students to occupy from first citizen of India to Local Leaders and Top most All India Civil Servants to Public Servants (The Annual Quality Assurance Report of IQAC Govt. Arts College, 2012-13). This college is catering to the poorest of poor in dry Rayalaseema region. Many people of this region rose from dust to doyen by this college. Higher education enrolment as well as literacy rate gradually rose due to this prestigious institution in the Rayalaseema region. The biggest labs in the college are evidence for so many scientific thoughts and experiments in the students. The NSS and NCC units in this institution mould so many discipline and committed volunteers towards social service. JKC has been providing so many employment opportunities to the poor students for the placements in different Multi-National Companies (The Annual Quality Assurance Report of IQAC Govt. Arts College, 2013-14).

In this college, Drama Hall became a cultural hub for many cultural activities in the city. Drama Hall witnessed so many public functions, retirement functions, literary and cultural functions. This institution is heart centre for conducting so many entrance tests and competitive examinations in the district. The college ground moulds many sportsmen, athletes and also useful for public. The college ground is an evidence for many political public and cultural meeting (The Annual Quality Assurance Report of IQAC Govt. Arts College, 2013-14).

The evolution timeline data shown in Table 1 shows that this institution accredited "A" grade by NAAC in 2005 and again it is Re-Accredited by " $A$ " grade with highest points in 2011. Arts College is the biggest College in the state by accommodating more than 7,000 students. Arts College celebrated Silver Jubilee in 1946, Golden Jubilee in 1978 and is going to Centenary Celebrations in 2016. Arts College describes as a temple of learning and in each academic year it is delivering thousands of well-educated students to the society. This college plays a vital role in the draught prone area in Rayalaseema region in the development of education which is the major mitigation factor to reduce the draught. This institution directly and in directly plays a significant role in the development of Rayalaseema region, especially in Ananthapuramu district. That's why many alumnus and public described this college as "Oxford University of Rayalaseema (The Annual Quality Assurance Report of IQAC Govt. Arts College, 2013-14)".

Table 1: Evolution Timeline of Govt. Arts College, Anantapur.

\begin{tabular}{ll}
\hline Year & Milestone events \\
\hline $\mathbf{1 9 1 4}$ & Madras Government took decision to start the college in Ceded Districts \\
$\mathbf{1 9 1 6}$ & Establishment of the College \\
$\mathbf{1 9 1 8}$ & Hostel was constructed \\
$\mathbf{1 9 2 0}$ & College was given First Grade Status, Inaugurated by Lord Pentland \\
$\mathbf{1 9 2 3}$ & TTC College attached \\
$\mathbf{1 9 2 6}$ & Affiliated to Andhra University \\
$\mathbf{1 9 2 8}$ & TTC College shifted to Bellary \\
$\mathbf{1 9 3 0}$ & Affiliated to Madras University \\
$\mathbf{1 9 3 1}$ & Former President of India, Neelam Sanjeeva Reddy was a student. \\
$\mathbf{1 9 4 0}$ & Ambulance Division, affiliated to St. John Ambulance Brigade of Madras \\
$\mathbf{1 9 4 4 - 4 5}$ & UOTC Started, which formed a part of the First Madras Battalion \\
$\mathbf{1 9 4 7}$ & Govt. Arts College became lead college \\
$\mathbf{1 9 5 4}$ & Affiliated to SV University \\
$\mathbf{1 9 6 4}$ & Silver Jubilee Celebrations \\
$\mathbf{1 9 6 5}$ & Acquisition of 2(f) \&12(B) from UGC \\
$\mathbf{1 9 7 8}$ & Golden Jubilee Celebrations \\
$\mathbf{2 0 0 5}$ & Accredited with 'A' grade by NAAC \\
$\mathbf{2 0 1 1}$ & Re-Accredited with 'A' grade by NAAC \\
$\mathbf{2 0 1 4}$ & Women's Hostel Inaugurated (UGC Funds) \\
$\mathbf{2 0 1 5 - 1 6}$ & Centenary Celebrations of Govt.Arts College \\
\hline Source: Proposal report for Autonomous Govt. Arts College, 2015.
\end{tabular}


The old college building is amazing with rare galleries and monumental labs. The government and the public both have responsibility to protect this historical, prestigious and marvellous building to light the future generations. Thus the marvellous building has to be declared as cultural heritage site by the government. The Government has to think to establish hospital and bank for college development. The college development council should think for providing better drinking water and sanitation facilities for the student community. The college staff should visit in teams to the various prestigious institutions in the country to know the better practices for implementation in this college. It may be advised to recruit separate committed staff to maintain the standards of this historic institution. By this we can flow good ideals and traditions in the students. In the globalization, privatization and liberalization the competition went to global level. To reach global skills and performance in students, the college must adopt new innovative approaches and methods (The Annual Quality Assurance Report of IQAC Govt. Arts College, 2014-15).

\section{Conclusion}

This in short is the brilliant saga of this college, the premier and pioneer institution in Rayalaseema. It is and has been producing many a gem of purest ray serene. The great past ought to be followed by a greater future and this college becomes in the fullness of the time the nursery of new rays of talented and worthy citizens. The traditions of this institution would serve as beacon light to the future generations of students.

This institution has been looked upon as a symbol of educational and cultural aspiration by generations of students. It has reflected the great tradition and culture of the people of Rayalaseema and has built up a reputation has one of the finest education institution in the country, which has shaped and moulded the character and personality of thousands of young men of Rayalaseema area who passed through its portals. Arts College lit the lamp of higher education in Rayalaseema. This college will march from glory to glory as its proceeds golden jubilee to centenary celebrations.

Evolution Timeline of Govt. Arts College, Anantapur has been shown in Table 1 which indicates that it is and has been producing many a gem of purest ray serene. The great past ought to be followed by a greater future and this college becomes in the fullness of the time the nursery of new rays of talented and worthy citizens. The traditions of this institution would serve as beacon light to the future generations of students. The college withstood the onslaught of social, political and economic changes and emerged as a towering champion of education for the upliftment of the poor and the downtrodden sections of the society. It brought about a profound intellectual transformation in Rayalaseema. 100 years of service by this noble institution in the then backward and still backward districts of Rayalaseema is a milestone in the cause of higher education, enlightment and bringing about awareness among the poorest of the poor people's social, economic and political rights.

\section{References}

RamachandraRao PS (1978) Golden Jubilee celebrations Souvenir Govt. College, Anantapur.

Foundation stone of Ceded District College (1918) Anantapur.

Foundation Stone of Ceded District College, Anantapur Hostel Building, 1917

Foundation Stone of Ceded District College (1930) Anantapur New Hostel Building.

Sivasankaranarayana B (1970) Andhrapradesh District Gazetteers, Anantapur, Govt. Secretariat Press, Hyderabad, p-671

Foundation Stone, Renovated Library Block of Govt. College (1993) Anantapur.

Foundation Stone, Govt. Arts College (2005) Anantapur, 'A' Grade by NAAC.

Foundation Stone, Govt. Arts College (2011) Anantapur, Entrance Gate.

Reaccreditation Report, Govt. Arts College (2011) Anantapur.

The Annual Quality Assurance Report of IQAC Govt. Arts College (2012-13) Anantapur.

The Annual Quality Assurance Report of IQAC Govt. Arts College (2013-14) Anantapur.

The Annual Quality Assurance Report of IQAC Govt. Arts College (2014-15) Anantapur.

Proposal report for Autonomous Govt. Arts College (2015) Anantapur. 